World Lumen Congress 2021 | May 26-30, 2021 |

Iasi, Romania

\title{
Analysis of RO-LA Transport Systems, Possibilities of Implementation in Romania
}

\author{
Marius GÎRTAN, Valeriu Stelian NIȚOI, \\ Constantina CHIRIAC
}

https://doi.org/10.18662/wlc2021/26

How to cite: Gîrtan, M., Niţoi, V.S., \& Chiriac, C. (2021). Analysis of ROLA Transport Systems, Possibilities of Implementation in Romania. In A. Sandu (vol. ed.), Lumen Proceedings: Vol. 17 World Lumen Congress 2021 (pp. 249-282). Iasi, Romania: LUMEN Publishing House. https://doi.org/10.18662/wlc2021/26 


\title{
Analysis of RO-LA Transport Systems, Possibilities of Implementation in Romania
}

\author{
Marius GÎRTAN¹, Valeriu Stelian NIT,OI² Constantina CHIRIAC ${ }^{3}$
}

\author{
Abstract
}

The paper brings to the fore the need for state support by making investments in railway infrastructure, in order to maintain and ensure the success of railway transport of trucks by introducing RO-LA transport in rail traffic. Using this mode of transport reduces the cost of maintaining road infrastructure, protects the environment, reduces fuel consumption, and reduces road traffic congestion RO-LA transport is an alternative solution to auto transport and contributes to the streamlining of traffic of goods and people.

Keywords: RO-LA transport, traffic decongestion, loading-unloading, transfer maneuver, environmental impact, traffic, fuel.

\section{Introduction}

The concept of carrying road or armored vehicles on railway wagons appeared during the First World War, as a solution for their rapid supply in areas where complex military operations were taking place. Subsequently, starting with the fourth decade of the twentieth century, the solution was transferred to civilian activities, and a number of French, German or American companies conducted experiments with semi-trailers loaded on railway flat wagons. The first trains carrying heavy vehicles were put into service only in 1954, by the West German Railway (DB), on the Mühlheim Hamburg and Frankfurt am Main - Hamburg routes, then in 1960 by the French National Railway Company (SNCF), and in 1964, in Switzerland, on

\footnotetext{
${ }^{1}$ University Politehnica of Bucharest, Doctoral School of Transport, Splaiul Independenței nr.313 Bucharest,Romania, girtantoma@yahoo.com

${ }^{2}$ University Politehnica of Bucharest, Doctoral School of Transport, Splaiul Independenței nr.313 Bucharest,Romania, nitoivs@yahoo.com

${ }^{3}$ University Politehnica of Bucharest, Doctoral School of Transport, Splaiul Independenței nr.313 Bucharest,Romania, costina.barculet@yahoo.ro
} 
the Basel - Lugano route (Wenger, 2001).The system for the transport of heavy road vehicles on railway wagons has been associated with the acronym "Ro-La", from the German expression "Rollende Landstrasse", which can be translated as "rolling highway". It is equivalent, in English, to the terms "rolling motorway" (acronym "RoMo") or rolling highway. Alternative names are also used in various documents, such as "route roulante" or "chaussée roulante", with the acronym "CR", in Switzerland. In France, the name "autoroute feroviaire" is being employed, for both the transport of complete road vehicles and semi-trailers.

\section{Tehnical solutions}

The first Ro-La trains in Germany implemented a solution based on Rmmso 33 type 2-axle flat wagons, without uprights, with a floor at a height of $1250 \mathrm{~mm}$ above the top of the rail. The components of an articulated vehicle were loaded separately, on the sides of the wagons, by means of a concrete platform located at floor level, as follows: the front part (tractor head or truck) on a wagon while the rear part (trailer or semi-trailer) was loaded separately, on the next wagon in the train composition (Wenger, 2001).

Subsequently, over a period of more than 50 years, in France, Germany, Austria, Switzerland and Russia, concepts and technical solutions have been developed adapted to the characteristics and traffic conditions of the national infrastructures in these countries.

In the countries of northern, central and eastern Europe, wagons with small wheels and sunken platform, on 8, 10 or 12 axles, were spread, which were designed taking into account the need to frame the wagon - road vehicle within the limits imposed by the dimensions of free passage through alpine areas (especially when passing through tunnels). These wagons meet the conditions imposed by UIC Sheets no. 571-4 and 571-6, and each wagon can carry a single complete heavy vehicle (truck, road train consisting of a truck with a trailer or tractor unit and a semi-trailer). Depending on the characteristics of the route used (mountain, lowland), trains can consist of 19 - 26 Ro-La wagons and passenger wagons for driver transport.

The loading and unloading of road vehicles is carried out gradually, one by one, by means of a mobile ramp located at one of the ends of the train set. For safety reasons, the movement of road vehicles on the wagons is only allowed in the "forward" direction, with speeds of no more than 5 $\mathrm{km} / \mathrm{h}$, and a wagon-length room should be maintained between two successive moving vehicles (Rail Cargo Group, n.d.). The process of loading 
road vehicles on wagons takes between 30 to 45 minutes, while the process of unloading them is faster, taking between 20 to 30 minutes. In the worst case scenario, a heavy vehicle runs for about 10 minutes on specialized wagons (Direction des Affaires Economiques et Internationales Mission des Alpes et des Pyrénées, 2007).

Ro-La terminals can be built as independent facilities (e.g. Freiburg terminal), but also as sections inside logistics centers or container terminals (e.g. Ro-La terminals in Wels, Trento or Regensburg). They have a relatively simple configuration, and their facilities consist, in addition to lines, in concrete platforms located at the ends of clogged lines or between rails and lines for maneuvering road vehicles while loading / unloading on / off wagons, parking spaces, gates gauge, traffic lanes that connect the parking spaces and the loading - unloading platform of heavy vehicles and buildings with spaces for carrying out the various formalities in the terminal.

The solution of wagons with small wheels and submerged platform is criticized (Saint Pulgent \& Pellegrin, 2006; International Transport Forum, 2009; Railway Council, 2020) for:

a) very high pressure from the wheel-rail contact, which:

- requires the production of parts and components made of special steel, involving high costs for the purchase of wagons;

- generates higher rail wear than in the case of regular wheel wagons;

b) the higher number of complete rotations of the wheels per kilometer than in the case of regular size diameter wheels, which:

- leads to rapid wear of the wheels and bogie components, and consequently the need to carry out maintenance and repair operations after covering $80,000-100,000 \mathrm{~km}$, much more frequent than in the case of wagons with regular-size wheel. The high cost of maintenance is a direct consequence.

- causes wheel heating phenomena, which require the trains to stop on the way, resulting in an increase in transport time.

c) difficulties in transmitting the braking power to the rail surface, which required sophisticated and expensive solutions for the braking systems;

d) difficulties in cornering;

e) the risk of derailment when crossing overpasses, due to the small diameter of the wheels.

In addition, according to data provided by the Swiss combined transport operator Hupac, the purchase costs of wagons with small wheels and sunken platform are double while the maintenance costs are about 4 times higher than container-dedicated wagons (Hupac, n.d.). 
Due to the mentioned disadvantages, the wagons with small wheels and sunken platform were not approved in France (Saint Pulgent \& Pellegrin, 2006). The manufacturer Lohr designed and produced articulated wagons, with two low platforms, but with regular size diameter wheels (first generation Modalohr wagons), adapted to the conditions on the French railway infrastructure. A flat wagon may be loaded, as appropriate, with two tractor heads or a semi-trailer. The main feature of the wagons is that they allow the simultaneous and "horizontal" loading or unloading of road vehicles, and the development of these processes requires $30^{\circ}$ rotation of the wagon platforms by means of special equipment, located between the tracks of the terminal (Modalohr, 2008; Lohr Group, n.d.).

The first generation Modalohr wagons are used on the Aiton Orbassano Alpine Railway Highway and can be composed of shuttles consisting of a passenger car for truck drivers, 14 Modalohr articulated wagons ( 2 end wagons and 12 intermediate wagons) and 2 interoperable locomotives, which can run both in France and Italy. The transport capacity of such a shuttle is 18 complete trucks or 28 semi-trailers (Modalohr, 2008).

The advantage of the Modalohr system is the reduction of terminal parking times for road vehicles and wagons. Thus, the duration of the process which includes the unloading of the arrived trucks and the loading of others is about 40 minutes, in case of a set consisting of 14 wagons. At the same time, the trainset can only park in the terminal for one hour and 50 minutes (Direction des Affaires Economiques et Internationales Mission des Alpes et des Pyrénées, 2007).

Modalohr wagons have higher acquisition costs, but also lower maintenance and repair costs than small wheeled and sunken platform wagons.

The manufacturer Lohr also designed and made second and third generation Modalohr wagons, adapted and used only for the transport of semi-trailers.

A solution encountered in the case of the normal gauge $(1435 \mathrm{~mm})$ is the one adopted in the case of shuttles running through the Channel Tunnel, on the Coquelles (France) - Folkestone (UK) route and which was made possible due to the generous free passage gauge of the tunnel design. The wagons were designed as special, semi-open structures, with regular size diameter wheels and platforms located at normal heights above the top of the rails (Eurotunnel Le Shuttle Freight, n.d.; Societe, n.d.).

Eurotunnel operates 18 sets consisting of 2 locomotives, 1 passenger car (club), 3 wagons for loading - unloading heavy vehicles on / off Ro-La wagons and 30 or 32 Ro-La wagons for transporting a similar number of road vehicles. Out of these sets, 6 train sets are made up of Breda Fiat 
wagons, 9 are Arbel wagons, and 3 sets are made of WBV wagons. The latter entered the Eurotunnel park in 2017 and were purchased for EUR 40 million, which means a price of about EUR 400,000 / railcar (Eurotunnel Le Shuttle Freight, n.d.).

In the bilateral traffic between Romania and Bulgaria, between 1992 and 1995, liners consisting of Rgs type wagons with normal wheels were used, belonging to the Bulgarian national railway carrier BDZ, adapted to the transport of heavy vehicles. The loading and unloading of the vehicles was also performed in this case, serial, at one of the ends of the train set, by using a movable ramp (Railway Council, 2020; Tănăsuică, 2012).

Table no. 1 shows the technical specifications of Ro-La wagons.

\section{Organization of RO-LA transport services}

Ro-La services are organized and operate according to the "shuttle" model, without stops for attachments - detachments of wagons or loading unloading of road vehicles, between the same two terminals, located along the major road transport routes. Trains run according to established routes and frequencies based on the level of transport demand, regardless of the loading rate at any given time (Tamma, 2017; Hupac, n. d.; Okombi, n.d.; RALPIN AG, n.d.; Rail Cargo Group, n.d.).

Accompanied combined RO-LA transport requires specific activities and procedures that lead to resource consumption and have significant specific durations regardless of the technical solutions and the organization adopted, such as:

a) road transport, from the sender to the loading terminal of the road vehicle on the Ro-La train, respectively from the unloading terminal to final consignee;

b) administrative formalities in terminals;

c) loading / unloading of road vehicles on / off the indicated wagon;

d) the transfer maneuvers of the wagons between the Ro-La terminals and the stations servicing these terminals or vice versa, with train composition / decomposition, if the lengths of the lines in the terminals do not allow for such operations there;

e) railway transport;

f) the technological processes executed in the dispatching stations, along the way and from the destination, in accordance with the railway regulations and the prescriptions of the wagon manufacturers.

As a result, in Central Europe, users of Ro-La trains should show up at the terminal 2-3 hours before the train leaves. At the destination, they 
Marius GÎRTAN, et al. | Lumen Proceedings 17 | WLC 2021

spend another hour in the terminal and the station that serves it (Hupac, n. d.; Okombi, n.d.; RALPIN AG, n.d.; Rail Cargo Group, n.d.). This time can be seen by road hauliers as unproductive times, in which their own resources are used inefficiently. During the use of Ro-La services, they still incur certain expenses, such as depreciation or rent of road vehicles. 


\section{Marius GÎRTAN, et al. | Lumen Proceedings 17 | WLC 2021}

Table no. 1: Ro-La type wagon specifications (Federal Finances Administration, n.d., Austrian Federal Ministry of Transport, Innovation and Technology, n.d., Hupac, n.d.; Saint Pulgent \& Pellegrin, 2006)

\begin{tabular}{|c|c|c|c|c|c|c|c|c|c|c|c|}
\hline \multirow{2}{*}{\multicolumn{3}{|c|}{ Wagon series / type }} & \multirow{3}{*}{$\begin{array}{l}\text { Saadkms } 690 \\
\text { Bombardier }\end{array}$} & \multirow{2}{*}{$\begin{array}{c}\text { Saadkkms } \\
741 \\
\text { Greenbrier }\end{array}$} & \multirow{2}{*}{ Sdmmrs } & \multirow{2}{*}{$\begin{array}{l}\text { Modalohr } \\
\text { AFA (first } \\
\text { generation) }\end{array}$} & \multicolumn{2}{|c|}{$\begin{array}{c}\text { Eurotunnel - } \\
\text { ARBEL } \\
\end{array}$} & \multirow{2}{*}{\begin{tabular}{|c|} 
Flat wagon - \\
model 13- \\
4095 \\
(Ukraine)
\end{tabular}} & \multirow{2}{*}{\begin{tabular}{|c}
$\begin{array}{c}\text { Flat wagon } \\
\text { model 13- } \\
9961 \\
\text { (Russia) }\end{array}$ \\
\end{tabular}} & \multirow{2}{*}{$\begin{array}{c}\text { BRN flat } \\
\text { wagon } \\
\text { adapted } \\
\text { (India) }\end{array}$} \\
\hline & & & & & & & To load & To carry & & & \\
\hline \multicolumn{2}{|l|}{ Gauge } & {$[\mathrm{mm}]$} & & 1435 & 1435 & 1435 & \multicolumn{2}{|c|}{1435} & 1520 & 1520 & 1676 \\
\hline \multicolumn{3}{|l|}{ Axle number } & 8 & 10 & 12 & 6 & \multicolumn{2}{|c|}{4} & 4 & 4 & 4 \\
\hline \multirow{2}{*}{ Tare weight } & End wagon & \multirow{2}{*}[\mathrm{kg}]{} & 19500 & 21300 & \multirow{2}{*}{23600} & \multirow{2}{*}{40000} & \multirow{2}{*}{54000} & \multirow{2}{*}{34000} & \multirow{2}{*}{28000} & \multirow{2}{*}{30500} & \multirow{2}{*}{24390} \\
\hline & Intermediary wagon & & 18000 & 20000 & & & & & & & \\
\hline \multirow{2}{*}{\begin{tabular}{|l} 
Length \\
between \\
buffers \\
automatic \\
coupling \\
\end{tabular}} & End wagon & \multirow[b]{2}{*}[\mathrm{mm}]{} & 19745 & 20200 & \multirow[b]{2}{*}{19060} & \multirow[b]{2}{*}{32480} & \multirow{2}{*}{\multicolumn{2}{|c|}{$:$}} & \multirow[b]{2}{*}{22520} & \multirow[b]{2}{*}{21440} & \multirow[b]{2}{*}{$:$} \\
\hline & Intermediary wagon & & 19090 & 19390 & & & & & & & \\
\hline \multirow[b]{2}{*}{$\begin{array}{l}\text { Useful } \\
\text { length }\end{array}$} & End wagon & \multirow[b]{2}{*}[\mathrm{mm}]{} & 18600 & 18400 & \multirow[b]{2}{*}{18800} & \multirow[b]{2}{*}{$2 \times 14010$} & \multirow[b]{2}{*}{25200} & & & & \\
\hline & Intermediary wagon & & 19000 & 18750 & & & & 20000 & 17800 & 20000 & $:$ \\
\hline Width & & {$[\mathrm{mm}]$} & 2990 & 3000 & 2600 & 3095 & 4380 & 4120 & 3045 & 3200 & $:$ \\
\hline Useful width & & {$[\mathrm{mm}]$} & - & $\begin{array}{c}2520 / \\
2560 \\
\end{array}$ & $:$ & : & & 700 & 2500 & 3000 & $:$ \\
\hline Maximum & End wagon & {$[\mathrm{t}]$} & Standard 42 & 53.7 & 48.5 & $2 \times 38$ & & 14 & 48 & 55,5 & 56,88 \\
\hline payload & Intermediary wagon & [4] & 44 & 55 & & & & & & & \\
\hline Maximum as & xle payload & {$[\mathrm{kg}]$} & 8,25 & 7.5 & 6 & $\begin{array}{c}18,5-22,5- \\
18,5 \\
\end{array}$ & & 2,5 & $:$ & 21,5 & $:$ \\
\hline Wagon whec & elbase & {$[\mathrm{mm}]$} & 13700 & 12730 & 15900 & $2 \times 14400$ & & : & 17800 & 15500 & : \\
\hline
\end{tabular}


Marius GÎRTAN, et al. | Lumen Proceedings 17 | WLC 2021

\begin{tabular}{|c|c|c|c|c|c|c|c|c|c|}
\hline Bogie wheelbase & {$[\mathrm{mm}]$} & $750-700-750$ & $4 \times 700$ & 2200 & $\begin{array}{l}2000-1800- \\
2000\end{array}$ & : & : & : & : \\
\hline $\begin{array}{l}\text { Floor height above the top of the rail } \\
\text { on empty wagon }\end{array}$ & {$[\mathrm{mm}]$} & \begin{tabular}{|c|} 
Standard \\
$410 / 450$ \\
High tare \\
$430 / 470$ \\
Ultralow310/45 \\
0 \\
\end{tabular} & 480 & $:$ & 200 & : & 968 & 1100 & : \\
\hline $\begin{array}{l}\text { Floor height above the top of the rail at } \\
\text { a payload of } 13 \mathrm{t} \text { (empty vehicle) }\end{array}$ & {$[\mathrm{mm}]$} & 475 & 465 & 410 & : & : & 968 & : & : \\
\hline \multirow{2}{*}{\begin{tabular}{|l|l}
$\begin{array}{l}\text { Wheel } \\
\text { diameter }\end{array}$ & New \\
\cline { 2 - 2 } & Wear (Used) \\
\end{tabular}} & \multirow{2}{*}[\mathrm{mm}]{} & $360 / 380$ & 380 & 360 & $840-920-840$ & \multirow[b]{2}{*}{ : } & \multirow[b]{2}{*}{ : } & 957 & $:$ \\
\hline & & 355 & 335 & 325 & $:$ & & & $:$ & $:$ \\
\hline $\begin{array}{l}\text { Minimum cornering radius for single } \\
\text { wagon }\end{array}$ & & 80 & 120 & $:$ & 150 & : & $:$ & : & : \\
\hline $\begin{array}{c}\text { Minimum cornering radius for wagons } \\
\text { in composition of train sets }\end{array}$ & {$[\mathrm{m}]$} & 150 & 150 & 150 & 150 & : & : & : & $:$ \\
\hline Maximum speed & {$[\mathrm{Km} / \mathrm{h}]$} & 120 & 120 & 120 & 120 & 140 & 120 & 120 & $\begin{array}{l}\text { Loaded: } 65 \\
\text { Empty: } 75\end{array}$ \\
\hline Loading gauge & - & Fişa UIC 505-1 & $\begin{array}{c}\text { Fişa UIC } \\
505-1\end{array}$ & $\begin{array}{l}\text { Fişa UIC } \\
505-1\end{array}$ & $\begin{array}{l}\text { UIC GB1 şi } \\
\text { GI3 }\end{array}$ & UIC GC & $0-\mathrm{V}-\mathrm{M}$ & $1-\mathrm{T}$ & $\begin{array}{l}\text { Konkan } \\
\text { Railways }\end{array}$ \\
\hline Maintenance cost & {$[€ / \mathrm{km}]$} & $0,08-0,15$ & $0,08-0,15$ & $:$ & 0,062 & $:$ & $:$ & $:$ & $:$ \\
\hline Price & {$[€ /$ buc $]$} & 150,000 & 150,000 & $:$ & $\begin{array}{l}350,000- \\
457,000\end{array}$ & \begin{tabular}{|c|} 
around 400,000 \\
for WBV wagons
\end{tabular} & $:$ & : & $:$ \\
\hline
\end{tabular}




\section{Operation of the Ro-La system involves:}

a) allocation of human resources in terminals and related expenses for their operation;

b) choosing the most convenient railway routes (from the point of view of costs, duration, traffic conditions, etc.) which can result in significant differences compared to normal road routes. These may lead to greater distances for the whole of the combined transport segment (composed of the distance for rail and road transport in the initial and final segments) than those specific to door-to-door road transport. A relevant example is on the route Bucharest - Arad, where the usual road route (Bucharest - Piteşti Râmnicu Vâlcea - Sibiu - Deva - Arad) is about $550 \mathrm{~km}$, while the cheapest railway routes, through Orşova and Livezeni, respectively, are completely different, at a distance of over $600 \mathrm{~km}$.

c) the transport of "deadweight" of about 13 tons / wagon, related to the road vehicle's own weight. The negative impact can be illustrated with the example of a Ro-La train that would run on the route Bucharest Progresu - Chiajna - Videle - Caracal - Craiova - Filiaşi - Târgu Jiu - Livezeni - Simeria - Glogovăț, consisting of 21 Ro-La wagons with small wheels and the Saadkms series submersible platform, each loaded with a 33 gross tons heavy vehicle, a berth wagon and a generator wagon. In this case, the "deadweight" amounts to 273 tons, which represents $23.1 \%$ of the train's gross tonnage. Assuming that the goods inside the road vehicles (i.e. 420 tons) are carried in a train consisting of only 10 Eacs type wagons, based on calculations and data from CFR Marfă, the deadweight plus the wagon's own mass and the generator wagon's own mass lead to:

- an increase by $3.85 \%$ of the infrastructure track access charge;

- an increase by $34.1 \%$ of diesel consumption;

- an increase by $30.6 \%$ of electricity consumption for traction.

d) the ratio between the weight of the goods in road vehicles (the actually carried load - payload) and the low floor wagon's own weight as compared to conventional wagons. Thus, under the most favorable situations, i.e. in which the vehicle has a gross mass equal to the maximum allowed on roads and highways (44 t) and carries 31 net tons of goods.

e) a reduced transport capacity compared to trains composed of conventional wagons or container trains (Tănăsuică, 2012; Hupac, n.d.; Railway Council, 2020). Thus, a Ro-La train composed of wagons with small wheels or Modalohr wagons can carry goods with a mass of about $400-600$ 
tons, compared to values that reach 2000 tons, in the case of conventional traffic (especially for bulk goods). In mountain areas, which are limiting the composition of trains from 18 to 21 small wheeled wagons, resulting in the transport of a similarly reduced number of road vehicles, that is equivalent to a maximum of $40 \mathrm{TEU}$ (container loading capacity), which means half of the average performance of container trains (about 80 TEU);

f) the expenses with the acquisition and maintenance of small wheeled wagons or Modalohr wagons are much higher than for other types of wagons.

\section{RO-LA Bussines Organization}

In the early years, the West German Railways (Deutsche Bahn) carried out all the activities related to their development (the "single enterprise" model). In France, Switzerland or Austria, partnership management was preferred, in which the railways ensured only the traction of trains, while transport organizers / combined transport operators ensured the general organization, coordination of activities, marketing of the service, customer relations, supply of specialized wagons, and services related to RoLa transport (the "specialized enterprise" model). Later, the West German Railways outsourced as well the activities to transport organizers (for example, to Kombiverkehr) (Wenger, 2001).

It is noticeable that many of the combined transport operators were either directly set up by the railways in various countries or with their participation.

There are also cases where these companies have been wholly acquired by national railway undertakings (e.g. Oekombi in Austria).

Over the last ten years, the Ro-La transport business has undergone a number of reorganization processes, as follows:

a) in the case of the Alpine Aiton - Orbassano Railway Motorway, the French and Italian authorities tried, in 2009, to concession its operation, but the procedure eventually failed. This led further on to its operation by the joint venture Autostrada Ferroviaria Alpina (AFA), created by the national railway operators of France and Italy, which provide the towing of trains.

b) in Austria, until 2013, the general organization, coordination of activities, supply of wagons, customer relations and services related to Ro-La transport were carried out by the Oekombi combined transport operator. Oekombi ceased its activities following the decision of its owner, the national railway operator Rail Cargo Austria, to carry out these activities 
directly, by taking over the wagons and by means of its own dedicated internal structures, in which it placed the staff transferred from Oekombi. The reasons for the decision were to simplify processes, better communicate with customers and achieve internal synergies (Rail Cargo Group, n.d.).

c) in Switzerland, the federal authorities required in 2011, through the terms of conditions of a financial support program, that Ro-La traffic be managed by a single company. As a result, the Hupac company handed over the related activities related to the Basel-Lugano route to the Ralpin company, to which it also leased the related wagons in its ownership (Federal Finances Administration, 2018).

The current situation on the operational relations is set out in table no. 2 and can be characterized as follows:

a) the general organization, coordination of activities, customer relations, provision of wagons and services related to Ro-La transport were and are carried out both by transport organizers / combined transport operators (many owned by incumbent railway operators) and by operators, incumbent railways;

b) the towing of Ro-La trains was and still is provided only by traditional railway operators (most of them state-owned enterprises);

c) newly private railway operators entering the market do not show interest in putting Ro-La trains into service;

d) there is a tendency to concentrate activities on as few companies as possible. In some cases, these activities are taken over by a single company, which is also an incumbent railway carrier. 


\section{Marius GÎRTAN, et al. | Lumen Proceedings 17 | WLC 2021}

Table nr. 2: Ro-La transport routes over the period 2018-2020

(Tamma, 2017; Hupac, n.d.; Okombi, n.d.; RALPIN AG., n.d.)

\begin{tabular}{|c|c|c|c|c|c|c|c|c|c|c|c|c|c|c|c|c|c|c|}
\hline \multirow[b]{2}{*}{ Route } & \multirow[b]{2}{*}{ Direcțion } & \multirow[b]{2}{*}{ Year } & \multirow[b]{2}{*}{$\begin{array}{l}\text { Transport } \\
\text { organizer }\end{array}$} & \multirow{2}{*}{$\begin{array}{l}\text { Wagon / } \\
\text { Owner/ } \\
\text { Supplier }\end{array}$} & \multirow[b]{2}{*}{$\begin{array}{l}\text { Railway } \\
\text { carrier }\end{array}$} & \multirow{2}{*}{$\begin{array}{c}\text { Distanc } \\
\mathrm{e} \\
{[\mathrm{km}]}\end{array}$} & \multirow{2}{*}{$\begin{array}{c}\text { Maximu } \\
\text { m height } \\
\text { of the } \\
\text { road } \\
\text { vehicle } \\
{[\mathrm{m}]}\end{array}$} & \multirow[b]{2}{*}{$\begin{array}{l}\text { Compositi } \\
\text { on }\end{array}$} & \multicolumn{7}{|c|}{$\begin{array}{l}\text { Numberof } \\
\text { treains/day }\end{array}$} & \multicolumn{3}{|c|}{$\begin{array}{c}\text { Transport prieces } \\
\text { [EUR/road } \\
\text { vehicle] }\end{array}$} \\
\hline & & & & & & & & & & 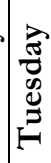 & 递 & 胥 & 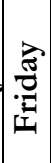 & 疍 & 疍 & $\begin{array}{l}<= \\
40 \mathrm{t}\end{array}$ & $\begin{array}{l}<= \\
42 \mathrm{t}\end{array}$ & $\begin{array}{l}<= \\
44 \mathrm{t}\end{array}$ \\
\hline \multirow{4}{*}{$\begin{array}{l}\text { Brenner } \\
\text { (Austria)-Worgl } \\
\text { (Austria) }\end{array}$} & Brenner - Worgl & \multirow{2}{*}{2010} & \multirow{2}{*}{ Oekombi } & \multirow{2}{*}{ Oekombi } & \multirow{4}{*}{$\begin{array}{c}\text { Rail } \\
\text { Cargo } \\
\text { Austria }\end{array}$} & \multirow{4}{*}{94} & \multirow{4}{*}{4} & \multirow{4}{*}{\begin{tabular}{|l|} 
Vagons \\
Saadkms \\
Bombardier \\
, Sdgmms
\end{tabular}} & 19 & 19 & 19 & 19 & 19 & 15 & 6 & \multirow{2}{*}{132} & \multirow{2}{*}{139} & \multirow{2}{*}{184} \\
\hline & Worgl - Brenner & & & & & & & & 19 & 19 & 19 & 19 & 19 & 13 & 8 & & & \\
\hline & Brenner - Worgl & 2018 & Rail Cargo & Rail Cargo & & & & & 17 & 18 & 18 & 18 & 18 & 14 & 9 & $\begin{array}{l}98- \\
133\end{array}$ & 188 & 221 \\
\hline & Worgl - Brenner & 2010 & Austria & Austria & & & & & 17 & 18 & 18 & 18 & 18 & 13 & 10 & $\begin{array}{c}120- \\
163\end{array}$ & 210 & 249 \\
\hline \multirow{4}{*}{$\begin{array}{l}\text { Salzburg } \\
\text { (Austria)- Fernetti } \\
\text { (Trieste, Italia) }\end{array}$} & $\begin{array}{l}\text { Salzburg - Fernetti } \\
\text { (Trieste) }\end{array}$ & \multirow{2}{*}{2010} & \multirow{2}{*}{ Oekombi } & \multirow{2}{*}{ Oekombi } & \multirow{4}{*}{$\begin{array}{c}\text { Rail } \\
\text { Cargo } \\
\text { Austria, } \\
\text { Mercitalia }\end{array}$} & \multirow{4}{*}{382} & \multirow{4}{*}{4} & \multirow{4}{*}{\begin{tabular}{|l|} 
Vagons \\
Saadkms \\
Bombardier \\
, Sdgmms
\end{tabular}} & 2 & 2 & 3 & 2 & 3 & 2 & 2 & \multirow{2}{*}{\multicolumn{3}{|c|}{360}} \\
\hline & $\begin{array}{l}\text { Fernetti (Trieste) - } \\
\text { Salzburg }\end{array}$ & & & & & & & & 2 & 2 & 3 & 2 & 2 & 2 & 3 & & & \\
\hline & $\begin{array}{l}\text { Salzburg - Fernetti } \\
\text { (Trieste) }\end{array}$ & 2018 & Rail Cargo & Rail Cargo & & & & & 1 & 0 & 1 & 0 & 0 & 1 & 0 & \multirow{2}{*}{\multicolumn{3}{|c|}{700}} \\
\hline & $\begin{array}{l}\text { Fernetti (Trieste) - } \\
\text { Salzburg }\end{array}$ & 2018 & Austria & Austria & & & & & 1 & 0 & 1 & 0 & 0 & 1 & 0 & & & \\
\hline \multirow{4}{*}{$\begin{array}{l}\text { Wels (Austria)- } \\
\text { Maribor } \\
\text { (Slovenia) }\end{array}$} & Wels - Maribor & 2010 & Oekombi & Oekombi & & & & & 3 & 3 & 3 & 3 & 3 & 2 & 1 & One & $y: 345$ & \\
\hline & Maribor - Wels & & & & Cargo & & & Saadkms & \begin{tabular}{|l|}
4 \\
\end{tabular} & 3 & 3 & 3 & 3 & 1 & 1 & Ret & trip & \\
\hline & Wels - Maribor & 2018 & Rail Cargo & Rail Cargo & Austria, & 341 & 4 & Bombardier & 2 & 2 & 2 & 2 & 2 & 3 & 1 & One & $y: 440$ & \\
\hline & Maribor - Wels & & & & & & & & 3 & 2 & 2 & 2 & 2 & 2 & 1 & & & \\
\hline
\end{tabular}


Marius GÎRTAN, et al. | Lumen Proceedings 17 | WLC 2021

\begin{tabular}{|c|c|c|c|c|c|c|c|c|c|c|c|c|c|c|c|c|c|c|}
\hline \multirow[b]{2}{*}{ Route } & \multirow[b]{2}{*}{ Direcțion } & \multirow[b]{2}{*}{ Year } & \multirow{2}{*}{$\begin{array}{l}\text { Transport } \\
\text { organizer }\end{array}$} & \multirow{2}{*}{$\begin{array}{l}\text { Wagon / } \\
\text { Owner/ } \\
\text { Supplier }\end{array}$} & \multirow{2}{*}{$\begin{array}{c}\text { Railway } \\
\text { carrier }\end{array}$} & \multirow{2}{*}{$\begin{array}{c}\text { Distanc } \\
\mathrm{e} \\
{[\mathrm{km}]}\end{array}$} & \multirow{2}{*}{$\begin{array}{c}\text { Maximu } \\
\mathrm{m} \text { height } \\
\text { of the } \\
\text { road } \\
\text { vehicle } \\
{[\mathrm{m}]}\end{array}$} & \multirow[b]{2}{*}{$\begin{array}{l}\text { Compositi } \\
\text { on }\end{array}$} & \multicolumn{7}{|c|}{$\begin{array}{l}\text { Numberof } \\
\text { treains/day }\end{array}$} & \multicolumn{3}{|c|}{$\begin{array}{c}\text { Transport prieces } \\
\text { [EUR/road } \\
\text { vehicle] }\end{array}$} \\
\hline & & & & & & & & & 胥 & 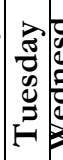 & $\sum_{0}^{0}$ & שֶ: & 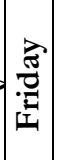 & 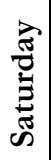 & 密 & $\begin{array}{l}<= \\
40 \mathrm{t}\end{array}$ & $\begin{array}{l}<= \\
42 \mathrm{t}\end{array}$ & $\begin{array}{l}<= \\
44 t\end{array}$ \\
\hline \multirow{4}{*}{$\begin{array}{l}\text { Worgl (Austria)- } \\
\text { Trento (Italia) }\end{array}$} & Worgl - Trento & \multirow{2}{*}{2010} & \multirow{2}{*}{ Oekombi } & \multirow{2}{*}{ Oekombi } & \multirow{4}{*}{\begin{tabular}{|c|} 
Rail \\
Cargo \\
Austria, \\
Mercitalia
\end{tabular}} & \multirow{4}{*}{233} & \multirow{4}{*}{4} & \multirow{4}{*}{\begin{tabular}{l|} 
Vagons \\
Saadkms \\
Bombardier \\
, Sdgmms
\end{tabular}} & 5 & 5 & 5 & 5 & 5 & 0 & 3 & \multirow{2}{*}{299} & \multirow{2}{*}{324} & \multirow{2}{*}{349} \\
\hline & \begin{tabular}{|l|} 
Trento-Worgl \\
\end{tabular} & & & & & & & & 5 & 5 & 5 & 5 & 5 & 3 & 0 & & & \\
\hline & Worgl - Trento & \multirow{2}{*}{2018} & \multirow{2}{*}{$\begin{array}{c}\text { Rail Cargo } \\
\text { Austria }\end{array}$} & \multirow{2}{*}{$\begin{array}{c}\text { Rail Cargo } \\
\text { Austria }\end{array}$} & & & & & \begin{tabular}{|l|}
1 \\
\end{tabular} & 1 & 2 & 2 & 2 & 0 & 1 & \multirow{2}{*}{$\begin{array}{c}217- \\
326\end{array}$} & \multirow{2}{*}{373} & \multirow{2}{*}{419} \\
\hline & Trento-Worgl & & & & & & & & 1 & 1 & 2 & 2 & 1 & 1 & 0 & & & \\
\hline \multirow{4}{*}{$\begin{array}{l}\text { Freiburg i. Br } \\
\text { (Germania).- } \\
\text { Novara (Italia) via } \\
\text { Elveția }\end{array}$} & $\begin{array}{l}\text { Freiburg i. Br. - } \\
\text { Novara }\end{array}$ & \multirow{2}{*}{2010} & \multirow{4}{*}{ Ralpin } & \multirow{4}{*}{ Ralpin } & \multirow{4}{*}{ SBB, BLS } & \multirow{4}{*}{482} & \multirow{4}{*}{3,96} & & 9 & 10 & 11 & 11 & 7 & 5 & 7 & Empty & hicle & $\begin{array}{l}300 \\
.480\end{array}$ \\
\hline & $\begin{array}{l}\text { Novara - Freiburg i. } \\
\text { Br. }\end{array}$ & & & & & & & Vagons & 10 & 11 & 11 & 11 & 9 & 5 & 3 & $\begin{array}{l}\text { Loadec } \\
-550\end{array}$ & & \\
\hline & $\begin{array}{l}\text { Freiburg i. Br. - } \\
\text { Novara }\end{array}$ & 2018 & & & & & & $\begin{array}{l}\text { Saadkms } \\
\text { Cattaneo }\end{array}$ & 8 & 10 & 10 & 10 & 9 & 5 & 7 & Empty & ehicle & $\begin{array}{l}390 \\
.520\end{array}$ \\
\hline & $\begin{array}{l}\text { Novara - Freiburg i. } \\
\text { Br. }\end{array}$ & 2018 & & & & & & & 10 & 10 & 10 & 10 & 10 & 5 & 4 & $\begin{array}{l}\text { Loadec } \\
620,65\end{array}$ & & \\
\hline
\end{tabular}




\section{REQUEST for RO-LA transport}

Between 1969 and 2018, Ro-La services were provided in Europe on a regular basis by at least 53 connections (13 domestic and 40 international) [9]. Of these, only 14 routes were operational in 2010, of which 4 are domestic and 10 international, while in 2018 only 9 routes are still operated, of which 2 are domestic and 7 international (table no.2) (Tamma, 2017; Hupac, n.d.; Okombi, n.d.; RALPIN AG., n.d.; Eurotunnel Le Shuttle Freight, n. d.).

Also, pilot Ro-La trains were tested on several routes, as follows:

a) Istanbul - Sofia - Belgrade - Ljubljana - Wels, in 2006. Transport was unaccompanied, with drivers traveling by plane and bus to the Wels terminal and back to Turkey. The experiment was considered technically successful, but was not followed by the organization of regular services, as no attractive rates could be offered on the market (International Transport Forum, 2009);

b) Moscow - Helsinki, Moscow - Poland and Moscow Novorosinsk, Moscow - Kaliningrad or Moscow - Ekaterinenburg. The first tests, carried out before 2010, ended with negative results, for technical reasons. Improved solutions have been provided and recent experiments showed that the movement of Ro-La trains is possible (Bakkal et al., 2009; Vrenken et al., 2013).

c) Bucharest Progresu - Videle - Craiova - Filiaşi - Livezeni - Simeria - Glogovăț, in 2009. The distance of $611 \mathrm{~km}$ was covered in 15 hours and 40 minutes (Tănăsuică, 2012);

d) Curtici - Simeria - Livezeni - Filiaşi - Craiova, in 2018. The train covered $411.8 \mathrm{~km}$ in less than 12 hours.

In what concerns the two experimental trains in Romania, the transport times corroborated with the durations spent in the terminals, upon loading and unloading vehicles on / off the wagons were longer than the possible transport times on the road.

In Romania, Ro-La trains ran regularly only in international traffic, on the following routes (Tănăsuică, 2012; Railway Council, 2020):

a) Bucharest Progresu - Kaspichan (Bulgaria), between 1992 and 1995. The trains consisted of wagons from the adapted Rgs series, belonging to the Bulgarian national railway carrier BDZ. The traffic was enabled by the comparatively long waiting times registered at the crossing of the Romanian - Bulgarian border and it stopped after the modernization of the Giurgiu Border Crossing Point; 
b) Glogovăț - Sopron (Hungary), in 1998. The trains were composed of small wheeled 8-axle wagons with sunken platform owned by the Hungarian national railway operator MAV (today, Rail Cargo Hungary) and it carried only 89 road vehicles, being canceled shortly after their putting into circulation, due to the lack of transport demand.

c) Bradu de Sus - Kaspichan (Bulgaria), in 2000. Adapted Rgs wagons were also used, and the trains only ran temporarily for a very brief period of time, due to the road carriers' lack of interest in such services.

d) Glogovăț - Wels (Austria), between 2002 and 2006, with Saadkms type 10-axle wagons with small wheels and sunken platform, in CFR Marfă's fleet;

e) Episcopia Bihor - Wels (Austria), between 2004 and 2006, also with Saadkms type 10-axle wagons with small wheels and sunken platform, in CFR Marfă's fleet.

The decline in the Ro-La traffic volume in Europe in 2018, as compared to 2010 can also be seen from the data specified in table no. 3 .

Table no 3: Ro-La trains currently running in Europe (Tamma, 2017; Hupac, n.d.; Okombi, n.d.; RALPIN AG., n.d.; Eurotunnel Le Shuttle Freight, n. d.)

\begin{tabular}{|c|c|c|c|}
\hline Route & Unit & $\mathbf{2 0 1 0}$ & $\mathbf{2 0 1 8}$ \\
\hline Eurotunnel & $\begin{array}{c}\text { [Trains/day and } \\
\text { direction] }\end{array}$ & $96-144$ & $96-168$ \\
\hline $\begin{array}{c}\text { Other relations in } \\
\text { Europe }\end{array}$ & [trains/ day] & $\begin{array}{c}\text { Sunday: } 52 \\
\text { Wednesday:10 } \\
8\end{array}$ & $\begin{array}{c}\text { Sunday: 45 } \\
\text { Wednesday: } 80\end{array}$ \\
\hline
\end{tabular}

In Austria, there is a general trend of significant decrease in traffic volume, measured in vehicles / year (Fig. No. 1). Given the disappearance of subsidies in some neighboring countries (e.g. Hungary) and the volume of demand, the national rail operator Rail Cargo Austria has restructured and concentrated traffic, with the result that services on some connections have been canceled and the total number of trains circulates on each operational relationship has decreased. Compared to 2010, the domestic services performed on the Salzburg - Villach route, the import - export traffic related to the Wels - Szeged route (Hungary) and the transit traffic Trento (Italy) Regensburg (Germany) disappeared (Okombi, n.d.; Rail Cargo Group, n.d.). Transport demand is maintained due to subsidies granted by the Austrian authorities and their environmental and road protection policy, which is reflected in high tolls (especially on the Brenner motorway) and the granting of a very small number of transit permits for road hauliers from non-EU 
countries (Austrian Federal Ministry of Transport, Innovation and Technology, n.d.; European Commission, n.d.; Tănăsuică, 2012).

In Switzerland, stagnation is the general trend (fig. No.2). This is due to the combined subsidies for accompanied transport and the very high tolls imposed by the federal authorities (Federal Finances Administration, 2018).

On the Aiton - Orbassano Alpine Railway Highway, the traffic volume has a generally growing trend, but not at the level desired by the French and Italian authorities (fig. 3). Demand is supported by significant subsidies (European Commission, n.d.; Saint Pulgent \& Pellegrin, 2006).

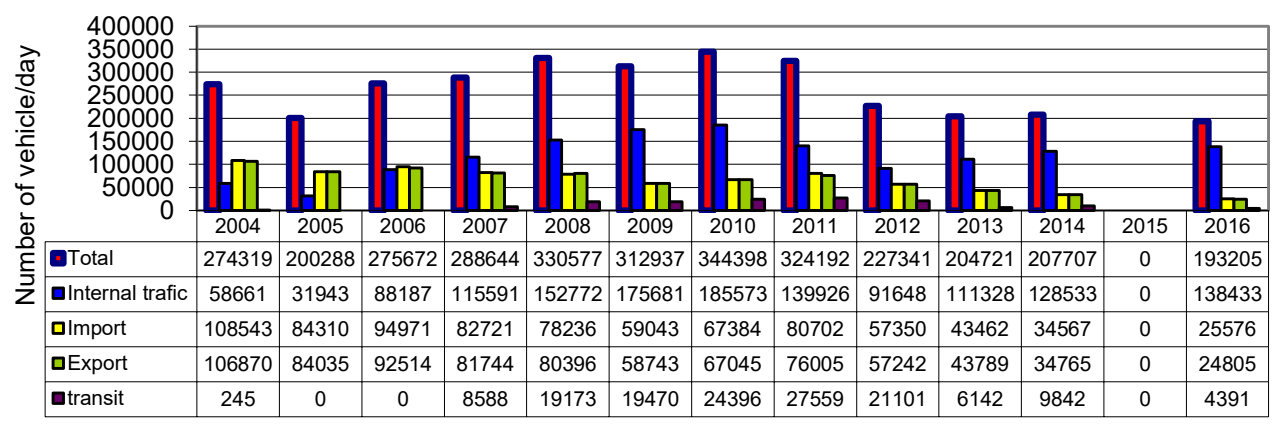

Fig 1.-Ro-La traffic volume in Austria (Eurostat data source)

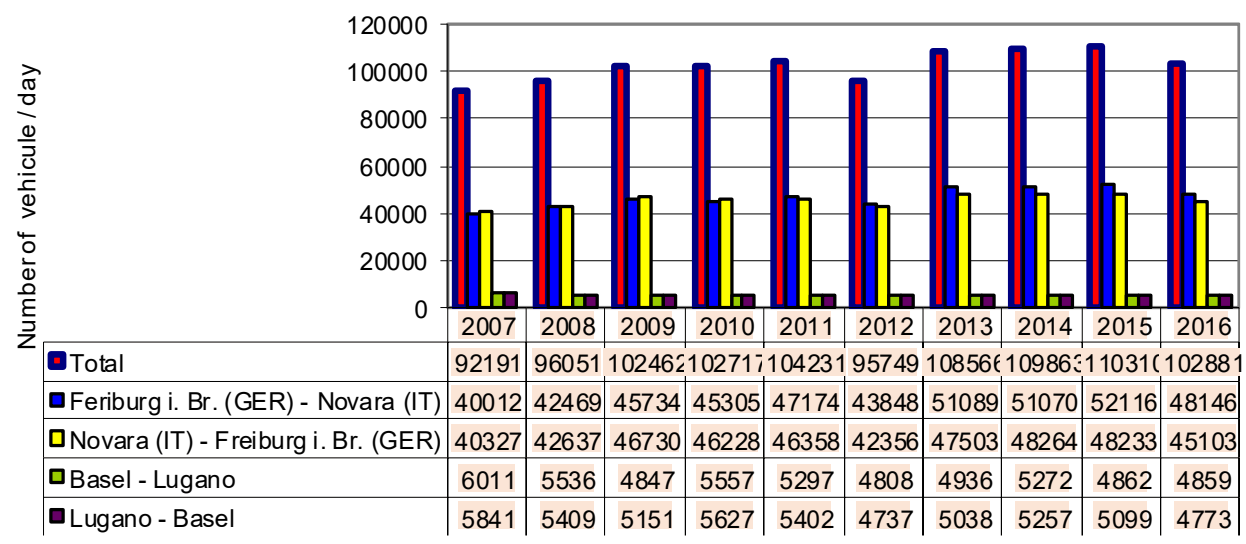

Fig. 2: Ro-La traffic volume in Switzerland

(Federal Finances Administration, 2018) 
Marius GÎRTAN, et al. | Lumen Proceedings 17 | WLC 2021

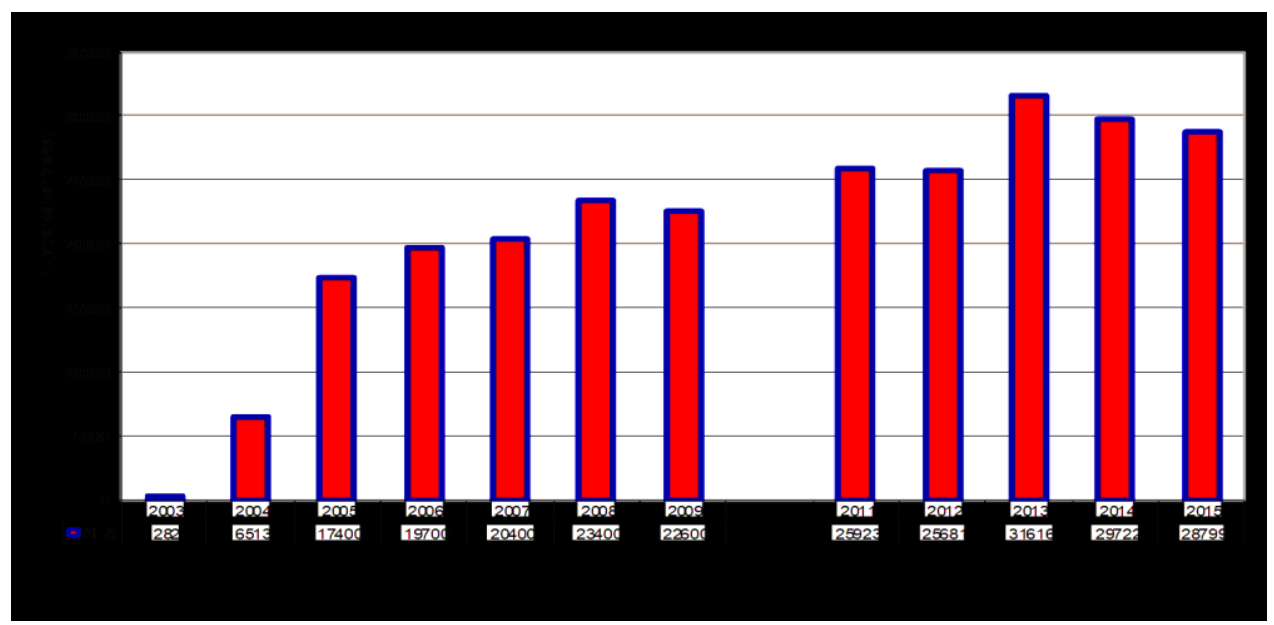

Fig. 3: Ro-La traffic volume on the Alpine Railway Highway

(Saint Pulgent \& Pellegrin, 2006)

The services organized through the Channel Tunnel stand as a success story, being favored by the geographical factor and the very high transport demand associated with economic exchanges between Great Britain and the countries of Continental Europe. They also have the advantage that their only competition comes from ferries, which are much slower and subject to occasional bad weather negative influence and sailing conditions at any given time. Although the French and British authorities do not grant subsidies, the volume of Eurotunnel traffic has a growth trend in general (fig. No. 4) (Eurotunnel Le Shuttle Freight, n.d.).

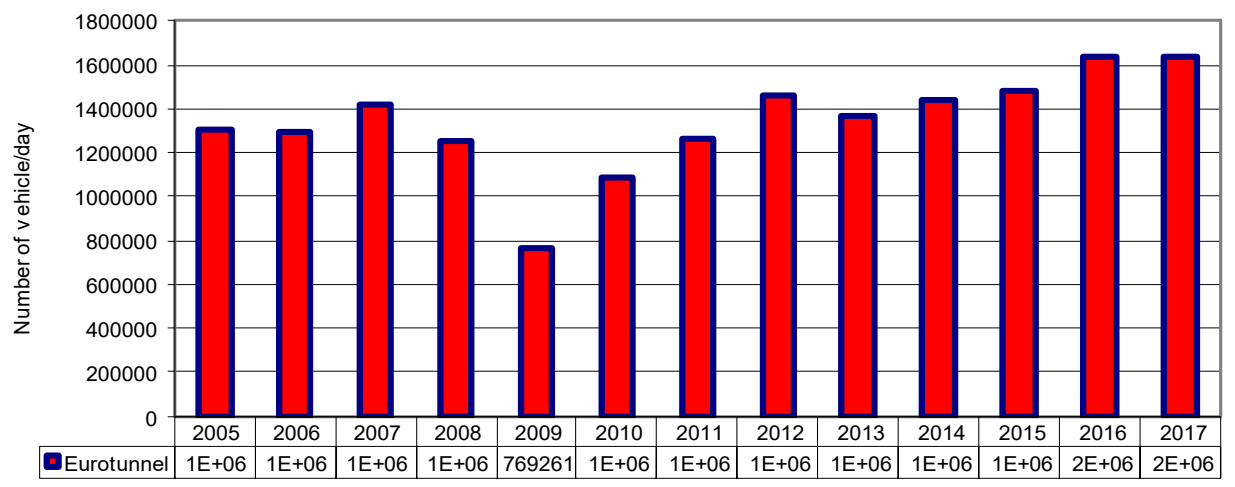

Fig. 4: The volume of Ro-La traffic through the tunnel under the English Channel (Eurotunnel Le Shuttle Freight, n.d.) 
Marius GÎRTAN, et al. | Lumen Proceedings 17 | WLC 2021

Table no. 4 presents the situation of Ro-La transports, on the relationship between Romania and Austria, from 2003 to 2006 (Tănăsuică, 2012)

\begin{tabular}{|c|c|c|c|c|}
\hline YEAR & $\mathbf{2 0 0 3}$ & $\mathbf{2 0 0 4}$ & $\mathbf{2 0 0 5}$ & $\mathbf{2 0 0 6}$ \\
\hline Number of trains & 596 & 890 & 805 & 506 \\
\hline Number of wagons & 12939 & 18563 & 13685 & 10850 \\
\hline $\begin{array}{c}\text { Number of road } \\
\text { vehicles }\end{array}$ & 10991 & 14082 & 11549 & 8080 \\
\hline & & & & \\
\hline
\end{tabular}

In 2007, after the accession of Romania and Bulgaria to the European Union, the transport demand vanished, as the customs formalities at the Romanian-Hungarian border were eliminated, and the movement of goods road vehicles registered in Romania or Bulgaria was overall smoother across the internal borders within the European Union, without transit authorizations that were previously granted in limited numbers. The same reasons affected the Ro-La Szeged (Hungary) - Wels (Austria) traffic (Railway Council, 2020; Tănăsuică, 2012).

Studies conducted by various organizations and the experience of combined transport organizers accumulated over 50 years reveal that the following aspects have an important impact on transport demand and the development of highways (Danielis et al., 2010; Federal Office of Transport, 2018; Ministere de la Transportation Ecologique et Solidaire, 2018; Railway Council, 2020; Tănăsuică, 2012; Wenger, 2001):

a) real benefits provided to customers. From this perspective, the applied tariff is essential and must be at a level that would result in a cost of the combined transport (railway tariff plus costs related to the initial and final road segments) which is lower than the door-to-door road transport. The transport time is the second most important element and must also be shorter than the time obtained by trucks on the road. It depends on the rail tracks' condition and other features of the railway infrastructure. Customers also appreciate the quality (especially punctuality) and flexibility of the service (especially the requirements for presentation at the terminal).

b) the running distance of Ro-La trains. Studies developed under the auspices of the International Union of Road Railway Combined Transport Companies (U.I.R.R.) show that the optimal traffic distance is about 300 $400 \mathrm{~km}$. At the same time, distances greater than $1000 \mathrm{~km}$ in conjunction with train travel times of 18-20 hours become unattractive for car drivers, who gave rejection feedbacks.

c) the free passage gauges of the railway lines, in Europe, preferring the routes allowing road vehicles of at least $4 \mathrm{~m}$ in height; 
d) natural or geographical factors, which may favor Ro-La services, as happens when crossing the English Channel.

e) the support granted by the public authorities through various measures (subsidies, traffic restrictions, high tolls, exemptions from paying taxes, etc.).

As such:

During the periods and on the routes where it enjoyed various advantages, the Ro-La train service reached remarkable average load rates (for example, $85 \%$ in case of trains from Austria or Switzerland, from Freiburg i. Br. - Novara);

- the disappearance of subsidies also generated the disappearance of Ro-La services (the case of services performed in domestic traffic in Germany and those on the Dresden-Lovosice and Szeged-Wels routes);

f) other political, economic or social factors such as:

- the accession of Eastern European countries to the European Union had negative effects, as the requirement to hold transit authorizations disappeared and customs formalities at the borders were eliminated. The consequence was the disappearance of the interest for accompanied transport and the cancellation of the circulation of some Ro-La trains, such as those on the relations Dresden (Germany) - Lovosice (Czech Republic), Glogovăț - Wels or Episcopia Bihor - Wels;

- the volume of traffic decreased during the economic crisis, which occurred in 2008. As the case may be, Ro-La services actually disappeared from some connections (e.g. Szeged - Ljubljana) or recorded significant losses in traffic volume due to the decrease in trade exchange between the European Union and Turkey.

- road transport companies face the risk of labor migration to competing companies, if they require their drivers to use Ro-La trains, especially if they establish their wages based on the distances actually traveled by road (as it happens in Romania).

Attempts to outline profiles of companies interested in Ro-La services lead to [6]:

a) companies that operate parks with less than 10 vehicles;

b) companies that do not have their own logistics network;

c) companies shipping goods on routes with unbalanced or irregular traffic volume; 
Marius GÎRTAN, et al. | Lumen Proceedings 17 | WLC 2021

\section{RO-LA Transport costs} table no.5.

The average costs of the Ro-La transports services are presented in

Table no. 5: The cost of Ro-La transport versus the cost of road transport, in Austria 2019

\begin{tabular}{|l|c|c|c|}
\hline Traffic type & $\begin{array}{c}\text { Road } \\
\text { transport } \\
\text { [Euro/1000 } \\
\text { tkm] }\end{array}$ & $\begin{array}{c}\text { Ro-La } \\
\text { transport } \\
\text { [Euro/1000 } \\
\text { tkm] }\end{array}$ & $\begin{array}{c}\text { Ratio between } \\
\text { road transport } \\
\text { cost and Ro-La } \\
\text { transport cost } \\
\text { [\%] }\end{array}$ \\
\hline Domestic traffic & 56 & 119.8 & $46.74 \%$ \\
\hline Import - export traffic & 56 & 81.8 & $68.46 \%$ \\
\hline Transit traffic & 56 & 103.5 & $54.11 \%$ \\
\hline National average & 56 & 102.5 & $54.63 \%$ \\
\hline
\end{tabular}

The comparison between road transport and accompanied combined transport, carrying a vehicle with a gross weight of 40 metric tons, over a distance of $825 \mathrm{~km}$, between Lüdenscheid (Germany) and Lecco (Italy), in transit through Switzerland, highlights the following costs (Federal Finances Administration, 2018) :

a) road transport cost: EUR 1,303 / vehicle;

b) the cost of combined transport along with:

- the cost of road transport on the initial and final segments: EUR 733 / vehicle;

- the cost of railway transport on the Novara - Freiburg i. Br.: route: EUR 865 / vehicle;

- total: EUR 1,598 / vehicle.

With regard to the Alpine Railway Highway, in publicly available documents (European Commission's decisions not to object to aid granted by the French and Italian authorities, etc.), the current costs have the status of confidential data (European Commission, n.d.). However, given the amount of total subsidies granted annually, the number of vehicles transported annually and the intensity of aid granted annually indicated in reports prepared by the Inspectorate General of Finance and the French Court of Auditors (Saint Pulgent \& Pellegrin, 2006), simple calculations allow for the following values to be established as total costs:

a) EUR 1,003.50 / vehicle, in 2010; 
b) EUR 585.90 / vehicle, in 2020 .

In Romania, the difference between the total cost of accompanied combined transport and the total cost of road transport leads to a need for state aid with an intensity of $60 \%$ of the total cost of accompanied combined transport (Fig. No. 5) European Commission, n.d.).

Fig. 5: Comparison between the total cost of the accompanied combined transport and the total cost of the road transport, in Romania (CFR Marfă source) transport less attractive in terms of environmental protection policies, as it generates a quarter of total greenhouse gas emissions in the European Union.

Fig. 5: Comparison between the total cost of the accompanied combined transport and the total cost of the road transport

\section{COSTS FOR BUCHAREST-ARAD \\ EURO/TRUCK}

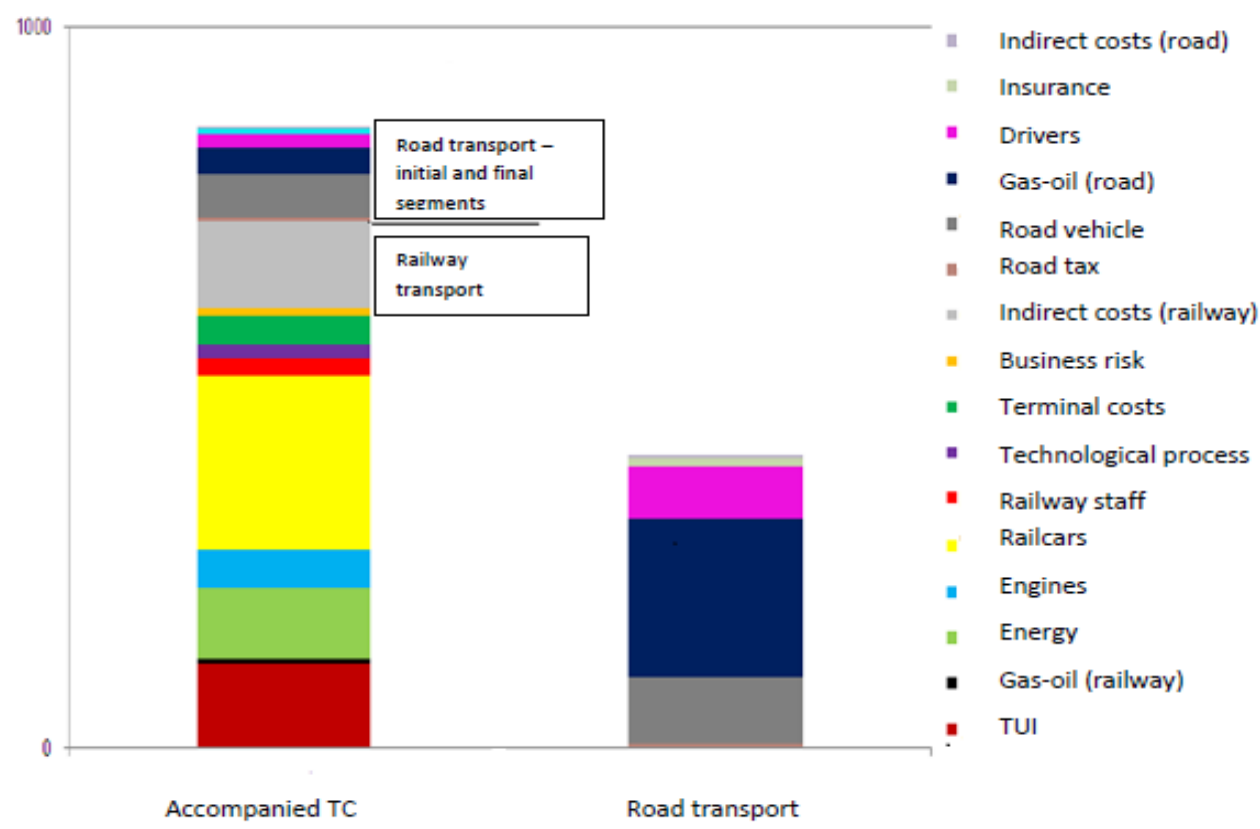


Marius GÎRTAN, et al. | Lumen Proceedings 17 | WLC 2021

\section{Possitive effects of Ro-LA transport}

The founders of RO-LA transport believe that this system is a solution for decongesting road maintenance costs, reducing the number of road accidents and protecting the enviroment by reducing polluants, noise and water pollution. By comparation, it makes road transport less atrractive in terms of enviromental protection policies, as it generates a quater of total greenhouse gas emissions in the European Union.

However, for RO-LA transport to be a reliable solution, the responsibility for its development and success lies with the states by financing transport infrastructures that generate value. The economic crisis of 2008 and the COVID-19 pandemic reduced investments in the transport sector.

Table no.6 Budgetary resources allocated to the EU transport sector for the period 2007-2020 (European Court of Auditors, 2018)

\begin{tabular}{|c|r|r|r|}
\hline \multicolumn{1}{c|}{ Tools } & $\begin{array}{r}2007- \\
2013\end{array}$ & $2014-2020$ & \multicolumn{1}{c|}{ Total } \\
\hline FEDER and CF/ ESI funds & 81,8 & 68,5 & 150,3 \\
\hline TENT & 8,00 & 0,00 & 8,00 \\
\hline Marco-Polo & 0,50 & 0,00 & 0,50 \\
\hline PC 7 Transports & 4,20 & 0,00 & 4,20 \\
\hline Orizont 2020 Transports & 0,00 & 6,30 & 6,30 \\
\hline
\end{tabular}

Source: European Court of Auditors (2018) based on data available to the public 
Table no. 7: External costs calculated with the unit values specific to the Romanian transport modes

\begin{tabular}{|c|c|c|c|c|c|c|c|c|c|c|c|c|c|c|}
\hline \multirow[b]{3}{*}{ Route } & \multirow{3}{*}{$\begin{array}{c}\text { External cost } \\
\text { item }\end{array}$} & \multirow{2}{*}{\multicolumn{2}{|c|}{ Traffic data }} & \multirow{2}{*}{\multicolumn{2}{|c|}{$\begin{array}{l}\text { External unit } \\
\text { costs }\end{array}$}} & \multirow{3}{*}{\begin{tabular}{|c|}
$\begin{array}{c}\text { External } \\
\text { costs } \\
\text { - Road } \\
\text { Transpo } \\
\text { rt }\end{array}$ \\
$\begin{array}{c}\text { Rail } \\
\text { transp. } \\
- \\
\text { electric } \\
\text { traction }\end{array}$ \\
\end{tabular}} & \multicolumn{4}{|c|}{$\begin{array}{c}\text { External costs - } \\
\text { Accompanied combined } \\
\text { transport }\end{array}$} & \multicolumn{3}{|c|}{$\begin{array}{l}\text { Savings external } \\
\text { costs }\end{array}$} & \multirow[b]{3}{*}{$\begin{array}{c}\text { Extern } \\
\text { al cost } \\
\text { in Euro } \\
/ \text { train }\end{array}$} \\
\hline & & & & & & & \multicolumn{2}{|c|}{$\begin{array}{l}\text { Road } \\
\text { segments }\end{array}$} & \multicolumn{3}{|c|}{ Diesel traction } & \multicolumn{2}{|c|}{ Electric traction } & \\
\hline & & $\begin{array}{c}\text { Road } \\
\text { vehicles } \\
\text { / route }\end{array}$ & $\begin{array}{c}\text { Net } \\
\text { tones } \\
/ \\
\text { road } \\
\text { vehicl } \\
\text { e }\end{array}$ & $\begin{array}{c}\text { Road } \\
\text { Transpo } \\
\text { rt }\end{array}$ & $\begin{array}{c}\text { Rail } \\
\text { transp. - } \\
\text { Diesel } \\
\text { traction }\end{array}$ & & $\mathrm{km}$ & $\begin{array}{c}\text { Euro / } \\
\text { train }\end{array}$ & $\mathrm{km}$ & $\begin{array}{c}\text { Extern } \\
\text { al cost } \\
\text { in Euro } \\
/ \text { train }\end{array}$ & $\mathrm{km}$ & $\begin{array}{c}\text { Extern } \\
\text { al cost } \\
\text { in Euro } \\
/ \text { train }\end{array}$ & $\mathrm{km}$ & \\
\hline \multirow{6}{*}{$\begin{array}{l}\text { Bucharest } \\
\text { - Arad } \\
\text { of which }\end{array}$} & Air pollution & 5 & 20 & 0,024 & 0,0131 & 0,0033 & 553 & 1327,2 & 50 & 120 & 27,4 & 35,89 & 583,6 & 192,59 \\
\hline & Climate change & 5 & 20 & 0,0116 & 0,0026 & 0,0016 & 553 & 641,48 & 50 & 58 & 27,4 & 7,12 & 583,6 & 93,38 \\
\hline & Noise & 5 & 20 & 0,0029 & 0,0015 & 0,0009 & 553 & 160,37 & 50 & 14,5 & 27,4 & 4,11 & 583,6 & 52,52 \\
\hline & Accidents & 5 & 20 & 0,0005 & 0,0014 & 0,0008 & 553 & 27,65 & 50 & 2,5 & 27,4 & 3,84 & 583,6 & 46,69 \\
\hline & $\begin{array}{c}\text { Traffic } \\
\text { congestion }\end{array}$ & 5 & 20 & 0,0034 & 0,0001 & 0,0001 & 553 & 188,02 & 50 & 17 & 27,4 & 0,27 & 583,6 & 5,84 \\
\hline & TOTAL & 5 & 20 & 0,0424 & 0,0187 & 0,0067 & 553 & 2344,72 & 50 & 212 & 27,4 & 51,24 & 583,6 & 391,01 \\
\hline \multirow{5}{*}{$\begin{array}{l}\text { Bucharest - } \\
\text { Timisoara } \\
\text { of which }\end{array}$} & Air pollution & 5 & 20 & 0,024 & 0,0131 & 0,0033 & 538 & 1291,2 & 100 & 240 & 27,4 & 35,89 & 583,6 & 192,59 \\
\hline & Climate change & 5 & 20 & 0,0116 & 0,0026 & 0,0016 & 538 & 624,08 & 100 & 116 & 27,4 & 7,12 & 583,6 & 93,38 \\
\hline & Noise & 5 & 20 & 0,0029 & 0,0015 & 0,0009 & 538 & 156,02 & 100 & 29 & 27,4 & 4,11 & 583,6 & 52,52 \\
\hline & Accidents & 5 & 20 & 0,0005 & 0,0014 & 0,0008 & 538 & 26,9 & 100 & 5 & 27,4 & 3,84 & 583,6 & 46,69 \\
\hline & Traffic & 5 & 20 & 0,0034 & 0,0001 & 0,0001 & 538 & 182,92 & 100 & 34 & 27,4 & 0,27 & 583,6 & 5,84 \\
\hline
\end{tabular}


Marius GÎRTAN, et al. | Lumen Proceedings 17 | WLC 2021

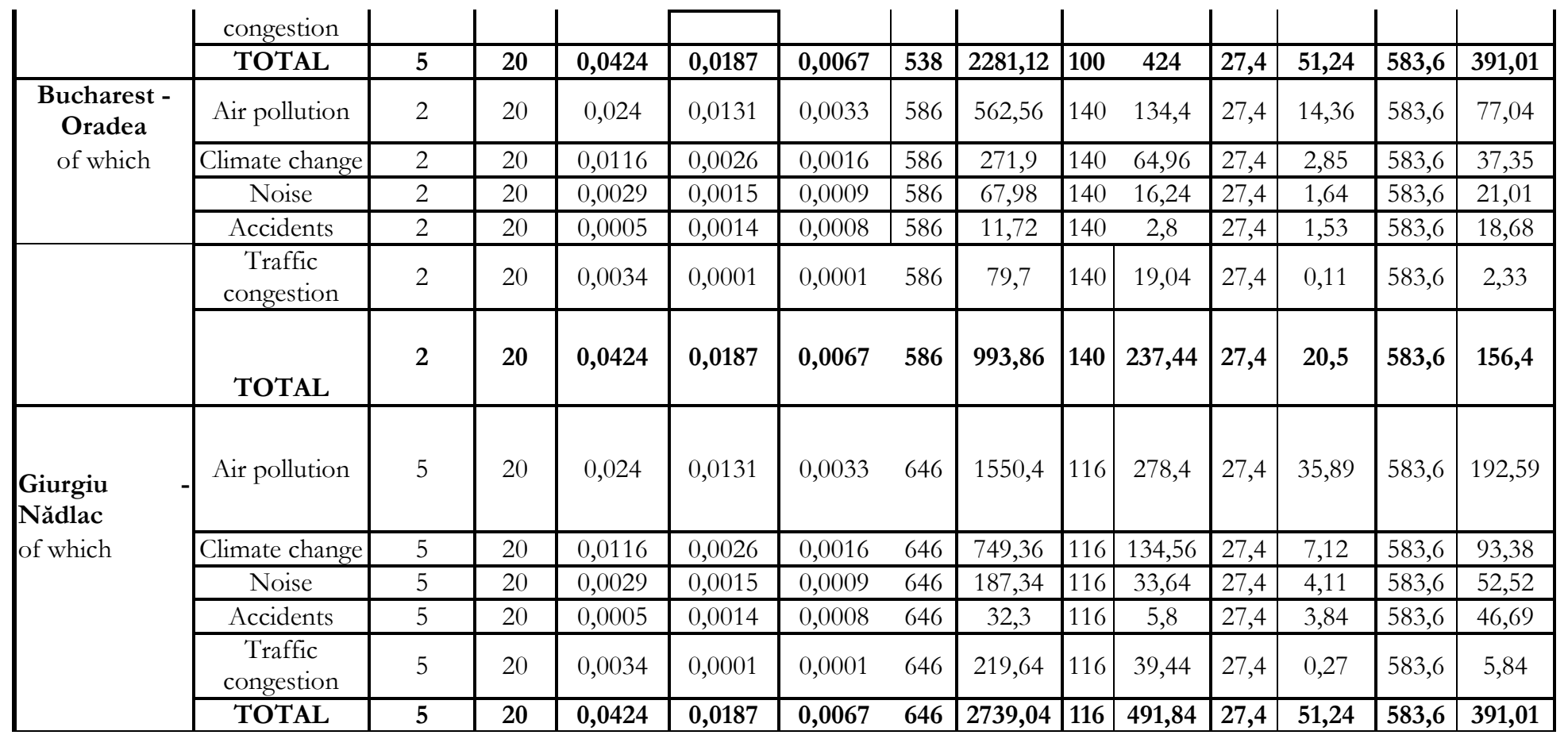


According to a study carried out by the Austrian national operator in collaboration with the Austrian Federal Office for the Environment, on the Worgl - Brenner route $(92 \mathrm{~km})$, each Ro-La train put into operation with a maximum load rate leads to reductions in carbon dioxide emissions of $70 \mathrm{~kg}$ in the Wörgl-Brenner direction, and $56 \mathrm{~kg}$, respectively, in the other direction (Rail Cargo Group, n.d.).

In what concerns the Alpine Aiton - Orbassano Railway Motorway, the modal shift of freight traffic from the road to the railway system allows the reduction of carbon dioxide (CO2) emissions by 5000 tons / year. Ro-La trains also make it possible to avoid the transport of dangerous goods by road, between France and Italy, via Ventimiglia, on routes of more than 700 $\mathrm{km}$, provided that the movement of heavy road vehicles loaded with such goods is prohibited in the Mont Blanc Tunnels and Frejus (European Commission, n.d.).

As for Romania, table no.7 presents the external costs saved by putting in operation a Ro-La train on the Bucharest Progresu - Glogovăț route, calculated on the basis of the unit valuesspecific to each mode of transport, indicated in the document "External - cost calculator for Marco Polo freight transport project proposal", developed by the Joint Research Center of the European Union.

\section{Supporting RO-LA transport}

Subsidizing Ro-La transport in the Member States of the European Union is only possible in compliance with the provisions of the OJEU (2008 / C / 184/07) "Community guidelines on State aid for railway undertakings". They restrict the possible state aid intensity as follows:

a) "in the case of aid for the use of infrastructure, $30 \%$ of the total cost of rail transport, up to $100 \%$ of the eligible costs";

b) in the case of aid to reduce external costs, $30 \%$ of the total cost of rail transport, up to a limit of $50 \%$ of the eligible costs";

c) exceeding the mentioned intensities is allowed exceptionally, provided that it can be argued that "the aid does indeed have a stimulating effect for the modal shift to the railways".

According to the European Commission's practice (n.d.), aid for the use of infrastructure means covering the infrastructure charge, the costs of transfer maneuvers between the railway stations and the Ro-La terminals they serve and the terminal charges. Also, by deciding not to object to the projects concerning the Alpine Railway Highway (France, Italy) or to the program promoted by the Administration of the Romanian Environmental 
Fund, it admitted aid intensities that only cover the difference between the cost of combined transport and the cost road transport.

Calculations made with data from Austria show that the normal intensities provided for by Community law do not allow for the compensation of all specific transport costs (European Commission, n.d.). Even when exceeding them is approved, the limitations imposed lead to rail fares comparable to the cost of door-to-door road transport. In such case, in the accounting systems of the road operators, the savings / reductions of diesel expenses, vehicle maintenance, personnel and some other taxes, which are brought forth as strengths by the promoters of the Ro-La system, will be canceled by the amounts paid for rail transport. With approximately equal total costs, road carriers will evaluate Ro-La transport according to criteria such as transport duration or quality of service. From this perspective, the transport times by rail together with the durations spent in the terminals (about 3 hours) and with the travel times of the initial and final road segments may exceed the duration of door-to-door road transport (as it was the case in Romania, demonstrated by tests and 2018). This fact does not virtually bring any real benefit to customers and does not guarantee the development of subsidized combined transport. It is therefore necessary that direct financial assistance be granted at the same time as other support measures.

Specifically, the Austrian authorities have supported and continue to support motorways by (Asfinag, n.d.; Austrian Federal Ministry of Transport, Innovation and Technology, n.d.; Tănăsuică, 2012):

a) direct financial support for the operation of Ro-La trains, which fall within the standard limits of European regulations, with the amounts indicated in table no.7. The beneficiaries of the aid can only be railway operators;

Table no. 8: Ro-La transport financial support in Austria (Austrian Federal Ministry of Transport, Innovation and Technology, n.d.)

\begin{tabular}{|c|c|c|c|c|c|c|c|}
\hline Corridor & Route & $\begin{array}{c}\text { Distance } \\
\text { to } \\
\text { Austria }\end{array}$ & $\begin{array}{l}\text { Total } \\
\text { distance }\end{array}$ & $\begin{array}{r}\text { Subsi } \\
{[\mathrm{Eu}} \\
\text { veh }\end{array}$ & $\begin{array}{l}2010 \\
/ \\
\text { e] }\end{array}$ & $\begin{array}{r}\text { Subsi } \\
{[\text { Ez }} \\
\text { veh }\end{array}$ & $\begin{array}{l}2018 \\
/ \\
\text { e] }\end{array}$ \\
\hline \multirow{5}{*}{$\begin{array}{l}\text { Corridor } \\
\text { Brenner }\end{array}$} & \multirow{2}{*}{$\begin{array}{l}\text { Brenner- } \\
\text { Worgl } \\
\end{array}$} & \multirow[b]{2}{*}{94} & \multirow[b]{2}{*}{94} & Day & 90 & Day & 77 \\
\hline & & & & Night & 45 & Night & 33 \\
\hline & \multirow{3}{*}{$\begin{array}{l}\text { Wörgl- } \\
\text { Rocanfort } \\
\text { (Trento) }\end{array}$} & \multirow{3}{*}{96} & \multirow{3}{*}{233} & \multirow{3}{*}{\multicolumn{2}{|c|}{90}} & Day & 77 \\
\hline & & & & & & Night & 33 \\
\hline & & & & & & \multicolumn{2}{|c|}{$\begin{array}{l}\text { + grants in } \\
\text { Italia (33 euro }\end{array}$} \\
\hline
\end{tabular}


Marius GÎRTAN, et al. | Lumen Proceedings 17 | WLC 2021

\begin{tabular}{|c|c|c|c|c|c|c|}
\hline & \multirow{4}{*}{$\begin{array}{l}\text { Rocanfort } \\
\text { (Trento)- } \\
\text { Regensburg }\end{array}$} & \multirow{4}{*}{73} & & & \multicolumn{2}{|c|}{ /vehicle) } \\
\hline & & & \multirow{3}{*}{463} & \multirow{3}{*}{90} & Day & 94 \\
\hline & & & & & Night & 47 \\
\hline & & & & & \multicolumn{2}{|c|}{$\begin{array}{c}\text { Trains } \\
\text { canceled }\end{array}$} \\
\hline $\begin{array}{l}\text { Corridor } \\
\text { Phyrn } \\
\text { Schober }\end{array}$ & $\begin{array}{l}\text { Wels - } \\
\text { Maribor }\end{array}$ & 325 & 341 & 75 & \multicolumn{2}{|c|}{77} \\
\hline \multirow{3}{*}{$\begin{array}{l}\text { Corridor } \\
\text { Tauern }\end{array}$} & \multirow[b]{2}{*}{$\begin{array}{l}\text { Salzburg- } \\
\text { Fernetti } \\
\text { (Trieste) }\end{array}$} & \multirow[b]{2}{*}{212} & \multirow[b]{2}{*}{382} & 80 & \multirow{2}{*}{\multicolumn{2}{|c|}{81}} \\
\hline & & & & $\begin{array}{c}\text { grants in } \\
\text { Italia (33 euro } \\
\text { / vehicle }\end{array}$ & & \\
\hline & $\begin{array}{l}\text { Salzburg- } \\
\text { Villach }\end{array}$ & 180 & 180 & 70 & $\begin{array}{r}\text { Tra } \\
\text { canc }\end{array}$ & \\
\hline \multirow[b]{2}{*}{$\begin{array}{l}\text { Corridor } \\
\text { Dunărea }\end{array}$} & \multirow[b]{2}{*}{$\begin{array}{l}\text { Wels - } \\
\text { Szeged }\end{array}$} & \multirow[b]{2}{*}{293} & \multirow[b]{2}{*}{648} & 70 & $\begin{array}{l}- \\
\text { subsi } \\
\text { gran }\end{array}$ & $\begin{array}{l}\text { No } \\
\text { y is } \\
\text { ed. }\end{array}$ \\
\hline & & & & $\begin{array}{l}+ \text { grants in } \\
\text { Ungaria }(6 € / \\
\text { tren-km, max } \\
2500 € / \text { tren })\end{array}$ & \multicolumn{2}{|c|}{$\begin{array}{l}\text {-Trains } \\
\text { canceled. }\end{array}$} \\
\hline
\end{tabular}

b) aid for the construction and development of terminals;

c) aid for the purchase of equipment used in combined transport;

d) exemption from the payment of the tax for road vehicles used exclusively in combined transport;

e) reimbursement of $15 \%$ of the monthly toll for road vehicles, for each ride on Ro-La trains;

f) exemption from the payment of tolls for foreign road carriers, within a radius of $70 \mathrm{~km}$ around the Wels terminal;

g) traffic bans for heavy vehicles, exceeding $3.5 \mathrm{t}$ :

- on Saturday, between 15:00 and 24:00;

on Sundays and public holidays: 00:00 - 22:00;

- bans during summer holidays: every Saturday,

- $\quad$ traffic bans at night, for vehicles exceeding $7.5 \mathrm{t}$ and which do not comply with the noise rules: 22:00 - 05:00;

Excepted from these prohibitions are those journeys carried out within a radius of $65 \mathrm{~km}$ around the combined transport terminals, including Ro-La. h) granting additional transit authorizations for users of Ro-La services from non-EU member countries. 
In all of the countries where Ro-La transport services are provided, the time spent by the road drivers on the Ro-La train is recognized as rest time.

Romania is a special case, due to the contradictory conditions in which highways can operate. Thus, on the one hand, a number of measures have been adopted to stimulate and develop them, and on the other hand, other measures continue to be favorable to the road system. The most important form of support for accompanied combined transport is direct financial support (subsidies), which can be granted by the Administration of the Environmental Fund, in the period 2018 - 2020, in amount of $60 \%$ of the VAT-free value of the invoice issued by the railway transport operator and with a maximum value RON 115 million over a three year period. In addition, there is in principle the decision of the Romanian railway infrastructure manager, adopted in May 2018, to grant 33\% discounts to the track access charge for trains providing intermodal traffic, including Ro-La trains.

The incentive effect of those measures is adversely affected by the existence of a general framework for providing rail or road transport services, which consists of the following:

a) the total amount of the track access charge (TUI) is high. For instance, in table no. 9, the actual values registered in the case of a road vehicle carried on a Ro-La train on the Bucharest Progresu - Glogovăț route are set out.

b) the road tax involves the payment of the so-called "rovignette" price, in amount of EUR 1,210 / year for trucks with the maximum total authorized mass over or equal to $12 \mathrm{t}$, with a minimum of 4 axles (inclusive). Given that such a vehicle drives on the average about $110,000 \mathrm{~km} /$ year, it is equivalent to EUR 1,210 / year: 110,000 km / year $=$ EUR $0.011 / \mathrm{km}$. As a result, for a road trip from Bucharest to Arad $(550 \mathrm{~km})$, the cost of using public roads is EUR $0.011 / \mathrm{km} \times 550 \mathrm{~km}=$ EUR 6.5. Therefore, the differences between this value and the railway track access charge are huge, as shown in table no. 9 . 
Marius GÎRTAN, et al. | Lumen Proceedings 17 | WLC 2021

Table no. 9: The fee for using the railway infrastructure (TUI) versus the price of the rovigneta, in the case of the Bucharest - Arad route

\begin{tabular}{|c|c|c|c|c|c|c|c|}
\hline \multicolumn{5}{|c|}{$\begin{array}{c}\text { Transport by train Ro-La București Progresu - } \\
\text { Glogovat }\end{array}$} & \multirow{2}{*}{\begin{tabular}{|c|c}
$\begin{array}{c}\text { Road } \\
\text { transport }\end{array}$ \\
$\begin{array}{c}\text { Road taxes } \\
{[\text { euro/vehicle] }}\end{array}$
\end{tabular}} & \multirow[t]{2}{*}{\begin{tabular}{|c} 
Raport \\
Whole \\
TUI \\
road \\
taxes \\
\end{tabular}} & \multirow[t]{2}{*}{\begin{tabular}{|c} 
Low \\
TUI \\
report \\
$/$ toll
\end{tabular}} \\
\hline $\begin{array}{c}\text { Number } \\
\text { of Ro-La } \\
\text { wagons } \\
/ \text { train }\end{array}$ & $\begin{array}{c}\text { Number } \\
\text { of } \\
\text { vehicles } \\
/ \text { train }\end{array}$ & $\begin{array}{l}\text { Train } \\
\text { load }\end{array}$ & \begin{tabular}{|c} 
TUI \\
integral \\
[euro / \\
[vehicle]
\end{tabular} & \begin{tabular}{|c|} 
TUI \\
$33 \%$ discount \\
[euro/vehicle]
\end{tabular} & & & \\
\hline 21 & 17 & $80 \%$ & 112,94 & 75,67 & 6,05 & 18,66 & 12,50 \\
\hline 21 & 21 & $100 \%$ & 92,30 & 61,84 & 6,05 & 15,25 & 10,22 \\
\hline
\end{tabular}

c) compared to other states, the price of the rovignette is $23-35$ times lower than the normal toll in Austria and about 38 times lower than in Switzerland. At the same time, the average value at the network level of the Romanian railway track access charge was, until the adoption of the intermodal traffic trains discount measure, of about $3.3-3.6$ euro $/ \mathrm{km}$, higher than in Austria, France, Italy or Slovenia and almost at the same value as in Switzerland.

d) a discount by $33 \%$ to the full amount of the railway track access charge may only be granted if the concerned railway operator incurs no overdue obligations or debts whatsoever to the payment of track access charges for other trains older than 30 days (which is an additional form of penalty, given that the infrastructure access contract provides anyhow for such interest penalty charges and the railway infrastructure manager may take, for example, the measure of stopping trains).

e) of the Competition Law no. 21/1996, as amended and republished in 2014, prohibiting economic agents from using their dominant position on the market (in this case, CFR SA) to apply to their trading partners (in this case, debtor railway operators with arrears to the payment of the track access charge) "unequal conditions to equivalent services, thus causing, to some of them, a disadvantage in their competitive position" (Romanian Parliament, 1996).

f) in Romania, the railway track access charge levels for passenger trains are lower than those for freight trains, unlike the countries in Western Europe, where the situation is the opposite. Given that rail passenger 
transport is subsidized, it can be stated that the approach of the authorities in Western countries also provides indirect support (non-existent in Romania) for rail freight traffic, including for trains related to combined or unaccompanied traffic.

g) the railway operators do not benefit from any kind of exemption or reduction of the excise tax included in the price of diesel fuel used in Diesel traction, as it happens in the road system. Given that part of the amount collected from excise duties is used for road maintenance, it follows that railway operators actually support road transport.

h) the Romanian authorities grant a significant number of transit authorizations for heavy road vehicles registered in non-EU member countries;

i) the Romanian authorities have not granted, so far, an exemption from the payment of the tax on means of transport (currently, tax) for vehicles used on the initial and final segments of the combined transport of goods, as provided by Directive no. 92/106 / EEC of 7 December 1992 on the establishment of common rules for certain types of combined carriage of goods between Member States, as amended following Romania's accession to the European Union (Eur-lex, 1992);

j) traffic restrictions or prohibitions for road vehicles with a maximum total authorized mass of more than 7.5 tons were imposed, by Government Decision no. 1777/2004, as subsequently amended, and the Order of the Minister Delegate for infrastructure projects of national interest and foreign investments no. 481 of December 20, 2013 / Order of the Minister of Internal Affairs no. 8 of January 23, 2014, on Fridays, Saturdays, Sundays and public holidays, as well as the periods and time intervals subject to restriction only on 4 sectors of European road and motorway and only during certain periods of the year and between certain hours.

It should also be noted that the mere existence of subsidies does not guarantee the emergence and development of Ro-La transport services.

This state of affairs can be motivated by the way in which the administrative processes required by the grant awarding procedures are carried out.

\section{Conclusion}

Based on the experience in Central and Eastern Europe or on the Alpine Railway Highway, it can be stated that Ro-La transport is a controversial solution, being simultaneously: 
a) very attractive, for the activists who militate for environmental protection and sustainable development, as well as for the general public who is not their direct user;

b) popular, for public authorities;

c) expensive and inefficient for traditional railway carriers;

d) uninteresting for the railway operators newly entered on the market;

e) at most indifferent, for road carriers;

f) unpopular, for drivers of heavy road vehicles.

The design and construction of Ro-La components has been and remains a challenge for engineers, but the marketing and development of roadways is only possible if road carriers make real gains from using them. As shown in the case of Eurotunnel, the success of Ro-La services occurs when natural and geographical factors are favorable and / or alternatives offer less favorable conditions. Otherwise, although Ro-La transports bring overall benefits to the population and can contribute to the sustainable development of society, it is utopian to rely on the civility and altruism of road transport companies, given the fierce competition between them.

The political and administrative factor can positively influence the transport demand by:

a) direct financial support (subsidies) for the operation of the Ro-La system;

b) direct financial support (subsidies) for the construction and modernization of terminals, and for the acquisition of specialized rolling stock, respectively;

c) fiscal measures (exemptions or reductions of taxes and duties);

d) the pricing policy of the railway infrastructure, respectively of the road infrastructure;

e) introduction of traffic restrictions for heavy road vehicles;

f) drastic limitation of the number of transit authorizations;

g) granting bonuses for Ro-La train users;

h) recognition of the duration of transport by Ro-La train as rest time for drivers;

i) internalization of external costs.

Support for the Ro-La system must be provided in an intelligent manner, so that no limitations and conditions would nullify the benefits it offers to road hauliers and the society. From this perspective, it is necessary to revise and amend accordingly the regulations setting out the procedures for granting direct financial aid for railway transport. 
Marius GÎRTAN, et al. | Lumen Proceedings 17 | WLC 2021

The analysis made in this paper highlights the development and evolution of Ro La (2010) transport as a future solution in European rail transport.

This paper studies the efficiency of Ro La (2010) transport over various distances and shows the importance of this type of transport for economic and social development.

\section{References}

Asfinag. (n.d.). Asfinag. Asfinag. https://www.asfinag.at/en/about-us/

Austrian Federal Ministry of Transport, Innovation and Technology. (n.d.). Austrian Federal Ministry of Transport, Innovation and Technology. BMK.

https://www.bmk.gv.at/

Bakkal, V., Kurennoy, V., Ledyaev, A., Korovyakovsky, E., \& Chubukov, A. (2009). About the level of development intermodal transportations in Russia and in the world. In O-P. Hilmola, \& E. Korovyakovsky (Eds.), „Fifth

International Railway Logistics Seminar: North-European Logistics in the Era of Global Economic Turmoil, Lappeenranta University of Technology, (pp. 19-36).

Lappeenranta University of Technology. http://ek0.ru/LUT/213 north eurasian logistics.pdf

Danielis, R., Rotaris, L., Buzzulini, L., \& Biktimirova, E. (2010). The choice between road transport and rolling motorway: a case study. Working Papers SIET 2010, 1-21.

https://citeseerx.ist.psu.edu/viewdoc/download?doi=10.1.1.665.633\&rep =rep1\&type $=$ pdf

Direction des Affaires Economiques et Internationales Mission des Alpes et des Pyrénées. (2007). Transports alpins. Les autoroutes ferroviaires alpines. DAEI.

Eur-lex. (1992). Directiva nr. 92/106 / CEE din 7 decembrie 1992 privind stabilirea de norme comune pentru anumite tipuri de transporturi combinate de mărfuri intre state membre [Directive no. 92/106 / EEC of 7 December 1992 laying down common rules for certain types of combined carriage of goods between Member States]. Eur-lex. https://eurlex.europa.eu/eli/dir/1992/106/2007-01-01/ron/pdf

European Commission. (n.d.). Competition Policy. European Commission. http://ec.europa.eu/competition/elojade/isef/index.cfm

European Court of Auditors (2018). Analiza panoramica. Către un sector performant al transporturilor in UE: provocările care trebuie abordate [Panoramic analysis. Towards a successful transport sector in the EU: the challenges to be addressed]. European Court of Auditors. https://op.europa.eu/webpub/eca/landscape-reviewtransport/ro/\#/table001

Eurotunnel Le Shuttle Freight. (n.d.). Eurotunnel Le Shuttle Freight. Eurotunnel 
Marius GÎRTAN, et al. | Lumen Proceedings 17 | WLC 2021

Freight. https://www.eurotunnelfreight.com/uk/home/

Federal Finances Administration. (2018). Publication of «Public finances 2018», Bern, Switzerland. https://www.efd.admin.ch/efd/en/home/the-fdf/nsbnews list.msg-id-74314.html

Federal Office of Transport. (2018). Evaluation der Rollenden Landstrasse. Federal

Audit Office. https://biblio.parlament.ch/e-docs/393381.pdf

Hupac. (n.d.). Hupac. Hupac. http://www.hupac.ch

International Transport Forum. (2009). Intermodal Transport. National Peer Review:

Turkey. Research Report. OECD Publications.

http://dx.doi.org/10.1787/9789282102237-en

Lohr Group. (n.d.). Lohr. Lohr. http://lohr.fr/

Ministere de la Transportation Ecologique et Solidaire. (2018). Autoroutes maritimes et

ferroviaires - Critères de choix par les entreprises pour le transport non accompagné.

CEREMA. https://www.cerema.fr/fr/centre-

ressources/boutique/autoroutes-maritimes-ferroviaires-criteres-choixentreprises

Modalohr. (2008). Projet de Service d'autoroute ferroviaire atlantique. Dossier de réponse de MOD ALOHR à la Consultation des concepteurs et constructeurs de matériels roulants. Docplayer. https://docplayer.fr/19987607-Projet-de-service-dautoroute-ferroviaire-atlantique.html

Okombi. (n.d.). Okombi. Okombi. http://www.okombi.at/

Rail Cargo Group. (n.d.). Rail Cargo Group. ROLA. https://rola.railcargo.com/en/b

Railway Council. (2020). Transportul feroviar de marfă în România. Studiu de piață

[Freight rail transport in Romania. Market research]. Consiliul Concurenței - Consiliul Naţional de Supraveghere în Domeniul Feroviar, Bucureşti

[Competition Council - National Council for Railway Supervision,

Bucharest]. http://www.consiliulferoviar.ro/wp-

content/uploads/2020/02/studiu transport marfa pt site.pdf

RALPIN AG. (n.d.). Ralpin. Ralpin. https:// ralpin.com/company/

Ro La. (2010). RoLa wagon for transport of empty and loaded trucks. Technical Bulletin. Greenbrier Europe.

Romanian Government. (2004, October 21). Hotărâre nr. 1.777 din 21 octombrie 2004

( ${ }^{*}$ actualizatä $\left.{ }^{*}\right)$ privind introducerea restrictiei de circulație pe unele sectoare de

autostrăzi şi de drumuri naționale europene (E) pentru vebiculele rutiere, altele decât cele destinate exclusiv transportului de persoane, în zilele de vineri, sâmbătă, duminică şi de sărbătoare legală**) (actualizată până la data de 6 februarie 2014*) [DECISION no. 1,777 of October 21, 2004 (* updated *) on the introduction of traffic restrictions on certain sections of European motorways and roads (E) for road vehicles other than those intended exclusively for the carriage of passengers on Fridays, Saturdays, Sundays and public holidays **) (updated to February 6, 2014*)]. 
Marius GÎRTAN, et al. | Lumen Proceedings 17 | WLC 2021

http://legislatie.just.ro/Public/DetaliiDocument/56479

Romanian Parliament. (1996, February 29). Legea nr. 21 din aprilie 1996

(*republicată*) legea concurenței [Law no. 21 of April 1996 (* republished

*) competition law]. Monitorul Oficial nr. 153 din 29 februarie 2016 [Official Gazette no. 153 of February 29, 2016].

http://legislatie.just.ro/Public/DetaliiDocument/8005

Saint Pulgent, N., \& Pellegrin J. (2006). Rapport d'enquette sur l'evaluation de l'autoroute ferroviaire alpine no. 2006-M-009-01. Vie-publique. https://www.viepublique.fr/rapport/28907-rapport-denquete-sur-levaluation-delautoroute-ferroviaire-alpine

Societe. (n.d.). IGF INDUSTRIES - ARBEL FAUVET RAIL. Societe.

https://www.societe.com/societe/igf-industries-arbel-fauvet-rail493467849.html

Tamma, P. (trans.), (2017, august 23). France and Italy seek operator to manage trans-Alpine line. Journal de l'environnement.

https://www.euractiv.com/section/railways/news/france-and-italy-seekoperator-to-manage-trans-alpine-line/

Tănăsuică, N. M. (2012). Transporturile Ro-La între politicile de dezvoltare durabilă şi viabilitatea comercială. Comparație între situațiile din România şi alte țări europene. Buletinul AGIR, Supliment 1, 141-147.

https://www.agir.ro/buletine/1606.pdf

Vrenken, H., Dashchenko, N., \& Jia, J. (2013). Study on introducing an intermodal (piggyback) transportation solution across the EU/CU border. Final report of the study under the Contract No. 2012/306038/1 concluded between the European Commission and EBRD Office for Economic Policy and Regional Development Ltd., Kielce, Poland, 2013. European Commission. http://www.ndptl.org/c/document library/get file?p $1 \mathrm{id}=12068 \&$ folder $\underline{\mathrm{Id}=16355 \& \text { name }=\text { DLFE-1606.pdf }}$

Wenger, H. (2001). L'UIRR à 30 ans. L'bistoire de l 'Union Internationale des Sociétés de Transport Combiné Rail-Route (UIRR) et du Transport Combiné de Marchandises Rail-Route en Europe, de 1970 à 2000. UIRR S.C. 